Research Article

\title{
Chloride-Binding Capacity of Portland Cement Paste Blended with Synthesized $\mathrm{CA}_{2}\left(\mathrm{CaO} \cdot 2 \mathrm{Al}_{2} \mathrm{O}_{3}\right)$
}

\author{
Yunsu Lee, Mingyun Kim, Zhengxin Chen, Hanseung Lee, and Seungmin Lim \\ Department of Architectural Engineering, Hanyang University, 55 Hanyangdaehak-ro, Sangnok-gu, \\ Ansan, Gyeonggi-do 15588, Republic of Korea \\ Correspondence should be addressed to Seungmin Lim; smlim09@gmail.com
}

Received 30 August 2017; Accepted 2 January 2018; Published 25 March 2018

Academic Editor: Charles C. Sorrell

Copyright (c) 2018 Yunsu Lee et al. This is an open access article distributed under the Creative Commons Attribution License, which permits unrestricted use, distribution, and reproduction in any medium, provided the original work is properly cited.

A chloride-binding capacity is the major factor to mitigate the ingress of chloride into concrete. This paper presents the chloridebinding capacity of Portland cement paste containing synthesized $\mathrm{CA}_{2}\left(\mathrm{CaO} \cdot 2 \mathrm{Al}_{2} \mathrm{O}_{3}\right)$. The $\mathrm{CA}_{2}$ was synthesized in the hightemperature furnace and characterized by X-ray diffraction for inspecting the purity. The synthesized $\mathrm{CA}_{2}$ was substituted for Portland cement by $0 \%, 5 \%$, and $10 \%$ by weight, and the $\mathrm{NaCl}$ solution was used as an internal chloride, which is assumed as a total chloride. The chloride-binding capacity of cement paste was calculated from a water-soluble chloride extraction method by the application of the Langmuir isotherm equation. And the hydration products were analyzed using X-ray diffraction and thermogravimetric analysis. We demonstrate that the $\mathrm{CA}_{2}$ increases an AFm phase in the Portland cement system, and the incorporation of $\mathrm{CA}_{2}$ consequently enhances the chloride-binding capacity of cement paste samples.

\section{Introduction}

Most modern structures are constructed using Portland cement as the primary material, but alternatives can be used, depending on specific environments. Calcium aluminate cement (CAC) exhibits excellent performance as a repair material, having higher early strength and a greater resistance against sulfate and abrasion than those of Portland cement [1-3]. CAC is also one of the materials that meet the global demand for reducing $\mathrm{CO}_{2}$ emissions [4].

CAC has a proportion of $40-80$ wt. $\% \mathrm{Al}_{2} \mathrm{O}_{3}$, higher than that of Portland cement which has $5-10 \mathrm{wt} . \%$ of $\mathrm{Al}_{2} \mathrm{O}_{3}$. CAC is also different from Portland cement in terms of the composition of the clinker. $\mathrm{C}_{3} \mathrm{~S}\left(3 \mathrm{CaO} \cdot \mathrm{SiO}_{2}\right)$ and $\mathrm{C}_{2} \mathrm{~S}$ $\left(2 \mathrm{CaO} \cdot \mathrm{SiO}_{2}\right)$ are the major clinkers in Portland cement, whereas $\mathrm{CA}\left(\mathrm{CaO} \cdot \mathrm{Al}_{2} \mathrm{O}_{3}\right)$ is used in CAC. In particular, white $\mathrm{CAC}$ (with a proportion of $\mathrm{Al}_{2} \mathrm{O}_{3}$ greater than $70 \mathrm{wt} . \%$ ) contains not only CA but also $\mathrm{CA}_{2}\left(\mathrm{CaO} \cdot 2 \mathrm{Al}_{2} \mathrm{O}_{3}\right)[1,2]$.

As the hydration products of $\mathrm{CAC}$ generate problematic phase conversions $\left(\mathrm{CAH}_{10}\right.$ or $\mathrm{C}_{2} \mathrm{AH}_{8}$ to $\mathrm{C}_{3} \mathrm{AH}_{6}$ ) depending on temperatures $[3,5]$, recent studies have focused on the improvement of the stability of CAC hydration products rather than the improvement of the strength of CAC binders [6-9].
CAC also has the drawback of reducing cost-effectiveness compared to Portland cement. As a result, studies on CAC incorporating Portland cement $[10,11]$, supplementary cementitious materials $[8,9,12,13]$, or chemical admixtures $[9,14]$ have been conducted to improve the stability and the durability of hydration products and economic benefits.

The hydration products of Portland cement blended with CAC are different depending on the ratios of Portland cement and CAC. If the proportion of CAC is more than $75 \%$, calcium aluminate hydrates (e.g., $\mathrm{CAH}_{10}, \mathrm{C}_{2} \mathrm{AH}_{8}$, and $\mathrm{C}_{3} \mathrm{AH}_{6}$ ) are generated. In contrast, if the proportion is less than $25 \%$, the AFm phase (e.g., $\mathrm{C}_{4} \mathrm{AH}_{\mathrm{x}}$ ) is higher than that of hydration products in Portland cement paste $[10,15]$. Based on the literature, this study focused on a Portland cement-based system with a proportion of CAC lower than $25 \%$, as it resolves the problems of economic feasibility as well as improves the binding capacity of the harmful ions of the binder owing to the high proportion of the AFm phase [16, 17].

The AFm phase consists of a layered double hydroxide structure, where anions (e.g., $\mathrm{OH}^{-}, \mathrm{CO}_{3}{ }^{2-}, \mathrm{SO}_{4}{ }^{2-}$, and $\mathrm{Cl}^{-}$) are combined between positively charged layers of divalent and trivalent cations as shown in Figure 1. The AFm phase has a different chemical composition according to the 


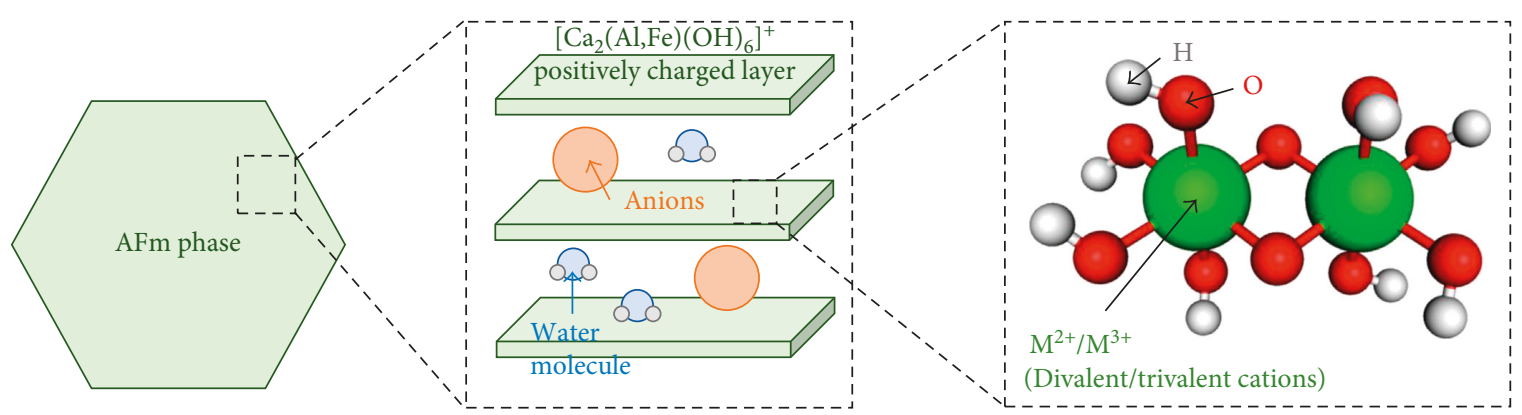

FIgURE 1: Structure of the AFm phase.

Table 1: Oxide composition of Portland cement.

\begin{tabular}{lccccccr}
\hline Oxide composition (wt.\%) & $\mathrm{SiO}_{2}$ & $\mathrm{Al}_{2} \mathrm{O}_{3}$ & $\mathrm{Fe}_{2} \mathrm{O}_{3}$ & $\mathrm{CaO}$ & $\mathrm{MgO}$ & $\mathrm{SO}_{3}$ & Loss of ignition \\
\hline PC & 19.29 & 5.16 & 2.87 & 61.68 & 4.17 & 2.53 & 2.49 \\
\hline
\end{tabular}

temperature, humidity, and the proportion of anions in the surrounding environments [18-21].

If the concentration of chloride ions is high within the AFm phase in concrete, the compounds where chloride ions are fixed between positively charged layers of the AFm phase increase $[19,22,23]$. This can effectively delay the penetration of chloride ions into concrete, as it reduces the amount of free chloride. It is well known that anhydrous $\mathrm{C}_{3} \mathrm{~A}\left(3 \mathrm{CaO} \cdot \mathrm{Al}_{2} \mathrm{O}_{3}\right)$, $\mathrm{C}_{4} \mathrm{AF}\left(4 \mathrm{CaO} \cdot \mathrm{Al}_{2} \mathrm{O}_{3} \cdot \mathrm{Fe}_{2} \mathrm{O}_{3}\right)$, and AFm family, which generally consists of monosulfoaluminate $\left(\mathrm{SO}_{4}\right.$-AFm), hydroxy-AFm $(\mathrm{OH}-\mathrm{AFm})$, and carbonate-AFm $\left(\mathrm{CO}_{3}-\mathrm{AFm}\right)$ in the Portland cement paste, reacts with chloride ions to form the bound chloride of the layer structure (Cl-AFm) [17, 22, 24-28]. However, as $\mathrm{C}_{3} \mathrm{~A}$, which plays an important role in the binding of chloride, is not suitable for mass concrete due to its high heat of hydration and low sulfate resistance, the proportion of $\mathrm{C}_{3} \mathrm{~A}$ is limited $[1,2,29]$.

In contrast, $\mathrm{CA}_{2}$ (a main clinker of the white CAC) is characterized by a low hydration reactivity and low heat of hydration [30]. As $\mathrm{CA}_{2}$ generates a hydrocalumite-type AFm phase by reacting with $\mathrm{Ca}(\mathrm{OH})_{2}$ in the same way as $\mathrm{C}_{3} \mathrm{~A}$, it plays an important role in the uptake of chloride ions [31-33].

In this study, we examine the applicability of $\mathrm{CA}_{2}$, focusing on a performance evaluation of clinker $\mathrm{CA}_{2}$ prior to a study on the utilization of white CAC. Specifically, this study aims to determine the effect of $\mathrm{CA}_{2}$ on chloridebinding capacity within a Portland cement-based system. Therefore, Portland cement paste containing synthesized $\mathrm{CA}_{2}$ is employed. This study also evaluates the chloridebinding capacity of the synthesized $\mathrm{CA}_{2}$ /Portland cement paste according to the amount of bound chloride and conducts a microanalysis on the hydrates.

\section{Materials and Methods}

2.1. Experimental Overview. $\mathrm{CA}_{2}$, the main material for this study, was synthesized in a high-temperature muffle furnace using industrial chemicals. The purity of the synthesized $\mathrm{CA}_{2}$ was analyzed using X-ray diffraction (XRD) and X-ray fluorescence (XRF).

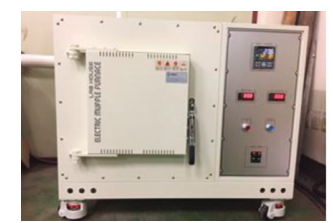

High-temperature furnace

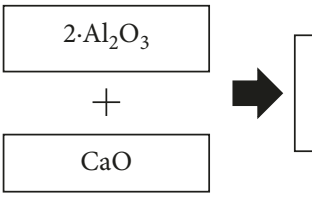

FIgure 2: Process of $\mathrm{CA}_{2}$ synthesis.

After determining the purity of the synthesized $\mathrm{CA}_{2}$, we analyzed the chloride-binding capacity of binders, in which $0 \%$, $5 \%$, and $10 \%$ of the cement (by mass) was replaced by $\mathrm{CA}_{2}$. An aqueous solution of chloride ions was prepared by dissolving $\mathrm{NaCl}$ in the mixing water. The amounts of mixed chloride ions were $0 \%, 0.25 \%, 0.5 \%, 1 \%, 2 \%$, and $3 \%$ of the binder mass. The cement paste was crushed at 28 days of curing, and the cement paste powder was analyzed via free chloride extraction, XRD, and thermogravimetric analysis (TGA).

\subsection{Materials}

2.1.1. Portland Cement. Type-1 ordinary Portland cement (Sungshin Cement, South Korea) was used, with the oxide composition analyzed via XRF. Table 1 presents the oxide composition of Portland cement.

2.1.2. Chloride Solution. Distilled water and a chloride ion solution were employed for preparing the cement paste. The chloride ion solution was made by mixing $\mathrm{CP}$-grade $\mathrm{NaCl}$ (DAJEONG, South Korea) with distilled water.

2.1.3. Calcium Oxide and Aluminum Oxide. CP-grade calcium oxide (DAJEONG, South Korea) and aluminum oxide powders (DAJEONG, South Korea) were used to synthesize $\mathrm{CA}_{2}$. 
TABLE 2: Mix proportion of cement paste.

\begin{tabular}{|c|c|c|c|c|c|}
\hline \multirow{2}{*}{ Binder type } & \multirow{2}{*}{ Water/binder ratio } & \multicolumn{2}{|c|}{ Binder (wt.\%) } & \multirow{2}{*}{ Chloride (wt.\% of binder) } & \multirow{2}{*}{ Note } \\
\hline & & Cement & Synthesized $\mathrm{CA}_{2}$ & & \\
\hline \multirow{6}{*}{ PC } & \multirow{18}{*}{0.5} & \multirow{7}{*}{100} & \multirow[t]{6}{*}{ 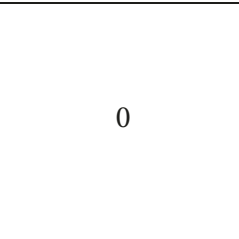 } & 0 & DW PC \\
\hline & & & & 0.25 & - \\
\hline & & & & 0.50 & - \\
\hline & & & & 1 & $1 \% \mathrm{Cl}^{-} \mathrm{PC}$ \\
\hline & & & & 2 & - \\
\hline & & & & 3 & $3 \% \mathrm{Cl}^{-} \mathrm{PC}$ \\
\hline \multirow{6}{*}{ CD5 } & & & \multirow{6}{*}{5} & 0 & DW CD5 \\
\hline & & \multirow{5}{*}{95} & & 0.25 & - \\
\hline & & & & 0.50 & - \\
\hline & & & & 1 & $1 \% \mathrm{Cl}^{-} \mathrm{CD} 5$ \\
\hline & & & & 2 & \\
\hline & & & & 3 & $3 \% \mathrm{Cl}^{-} \mathrm{CD} 5$ \\
\hline \multirow{6}{*}{ CD10 } & & \multirow{6}{*}{90} & \multirow{6}{*}{10} & 0 & DW CD10 \\
\hline & & & & 0.25 & - \\
\hline & & & & 0.50 & - \\
\hline & & & & 1 & $1 \% \mathrm{Cl}^{-} \mathrm{CD} 10$ \\
\hline & & & & 2 & - \\
\hline & & & & 3 & $3 \% \mathrm{Cl}^{-} \mathrm{CD} 10$ \\
\hline
\end{tabular}

\subsection{Experimental Procedure}

2.3.1. Synthesis of $\mathrm{CA}_{2}$. $\mathrm{CA}_{2}$ was synthesized by mixing combusting powders with calcium oxide $(\mathrm{CaO})$ and aluminum oxide $\left(\mathrm{Al}_{2} \mathrm{O}_{3}\right)$ in a high-temperature muffle furnace $[30,34]$. Figure 2 shows the process of $\mathrm{CA}_{2}$ synthesis, in which the molar ratio of $\mathrm{CaO}$ to $\mathrm{Al}_{2} \mathrm{O}_{3}$ is $1: 2$. The substances were stirred sufficiently for homogeneity, and the mixed $\mathrm{CaO}$ and $\mathrm{Al}_{2} \mathrm{O}_{3}$ powder was combusted in a high-temperature muffle furnace with a heating rate of $5^{\circ} \mathrm{C} / \mathrm{min}$ at a maximum temperature of $1550^{\circ} \mathrm{C}$. The final substance was maintained at $1550^{\circ} \mathrm{C}$ for two hours and then cooled down to room temperature.

The synthesized $\mathrm{CA}_{2}$ was analyzed by XRD, XRF, and scanning electron microscope (SEM). The XRD and XRF were performed using a RIGAKU D/MAX-2500 with $\mathrm{CuK} \alpha$ radiation of $100 \mathrm{~mA}$ and $40 \mathrm{kV}$, and the XRD measurement of the synthesized $\mathrm{CA}_{2}$ was conducted in a range of $5^{\circ}-55^{\circ}$ with a scanning rate of $4^{\circ} / \mathrm{min}$. The SEM analysis used a TESCAN Mira3.

2.3.2. Fabrication of Cement Paste Samples and Microanalysis. Cement paste sample incorporating synthesized $\mathrm{CA}_{2}$ was prepared according to the mix proportions in Table 2, which shows $0 \%, 5 \%$, and $10 \%$ (based on mass) of the cement being replaced by the synthesized $\mathrm{CA}_{2}$. The $\mathrm{NaCl}$ solution was used to evaluate the chloride-binding capacity of each cement paste. The chloride solution was prepared by mixing $0 \%, 0.25 \%, 0.5 \%, 1 \%, 2 \%$, and $3 \%$ of binder mass with distilled water.

The cement paste samples were then sealed and cured at $20^{\circ} \mathrm{C}$ for 28 days. The samples were crushed after 28 days for the chloride extraction test and microanalysis. The crushed samples were immersed in acetone for stopping hydration and then dried at $40^{\circ} \mathrm{C}$ in a few minutes. The dried samples were crushed one more time to be filtered through a $150 \mu \mathrm{m}$ sieve before use. The powdered samples were analyzed using
XRD and TGA (CuKa radiation, $100 \mathrm{~mA}, 40 \mathrm{kV}$ ). The measurement was conducted in a range of $5^{\circ}-60^{\circ}$ with a scanning rate of $4^{\circ} / \mathrm{min}$. TGA measurements were performed using the SHIMADZU DTG-60 instrument with approx. $40 \mathrm{mg}$ of the powdered sample analyzed at a heating rate of $20^{\circ} \mathrm{C} / \mathrm{min}$ in the $\mathrm{N}_{2}$ atmosphere.

2.3.3. Extraction and Detection of Soluble Chloride of Cement Paste. The extraction test for soluble chloride from the cement paste was conducted according to ASTM C1218 [35], and refer to existing studies [36, 37]. $1 \mathrm{~g}$ of a crushed sample was weighed and then added to $100 \mathrm{~mL}$ of distilled water, after which a chloride ion extraction test was conducted in a constant temperature bath at $60^{\circ} \mathrm{C}$ for five minutes. The sample was stabilized for 30 minutes, and then, the cement paste powder inside the aqueous solution was removed using a decompression filtration device. Obstacle factors from sulfide were removed from the filtered chloride ion solution using nitric acid $\left(\mathrm{HNO}_{3}\right)$ and hydrogen peroxide $\left(\mathrm{H}_{2} \mathrm{O}_{2}\right)$. Silver nitrate $\left(\mathrm{AgNO}_{3}\right)$ was then used in potentiometric titration experiments. Figure 3 shows the free chloride extraction and detection tests.

The $1 \mathrm{~g}$ of powder was used for the free chloride extraction test, and the amount of soluble chloride was expressed by wt.\% of the binder. The amount of bound chloride in each binder was calculated by subtracting the amount of measured water-soluble chloride from the total chloride content. The total chloride content was assumed to be the chloride content at the particular concentration that was added to the mixing water.

\section{Results and Discussion}

3.1. Synthesized $C A_{2}$. The purity of the synthesized $\mathrm{CA}_{2}$ was measured by XRD and XRF analyses. Figure 4 shows the XRD results after performing Rietveld refinement using 


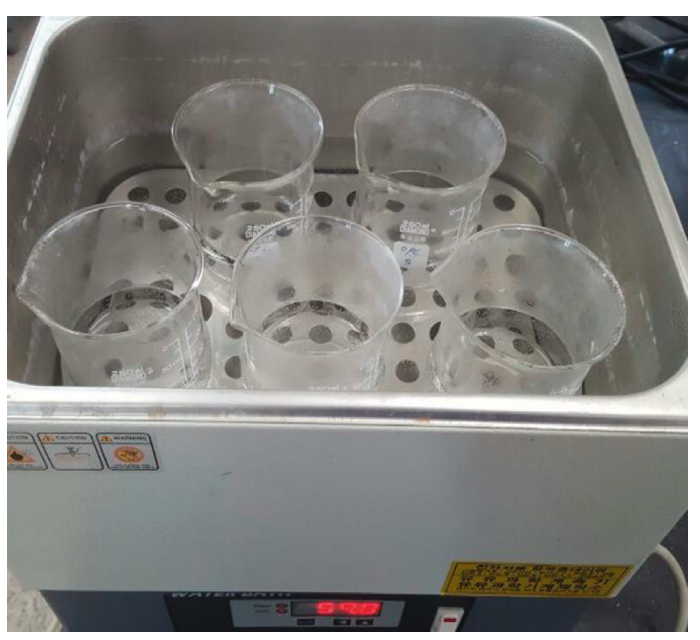

Free chloride extraction at $60^{\circ} \mathrm{C}$

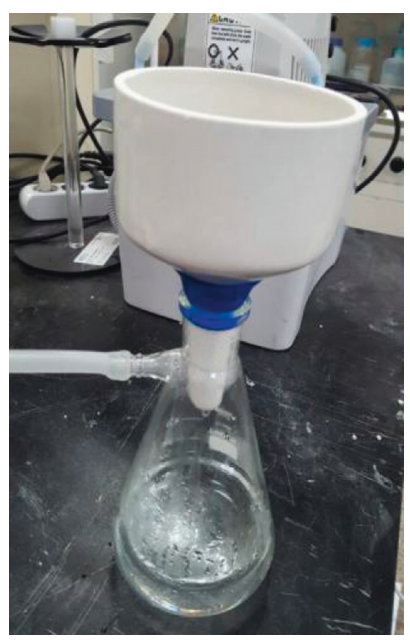

Vacuum filtration

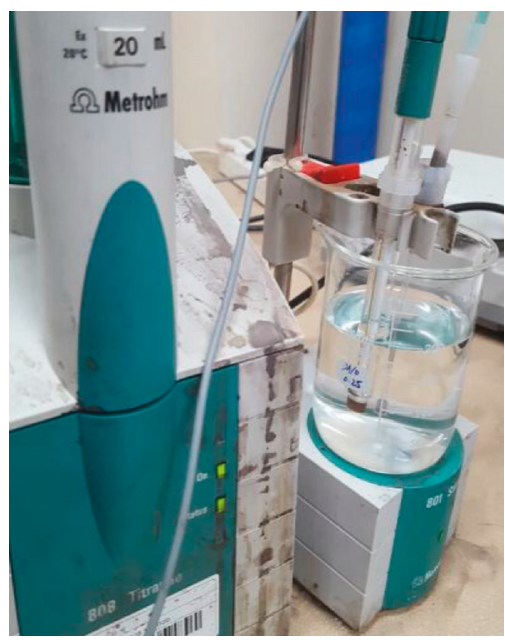

Potentiometric titration

Figure 3: Water-soluble chloride extraction and determination.

software Profex. The space group of $\mathrm{CA}_{2}$ is $\mathrm{C} 12 / \mathrm{cl}$, and its unit cell parameters are as follows: $a=12.89 \AA, b=8.89 \AA$, $c=5.44 \AA$, and $\beta=106.97^{\circ}$. The major three diffraction peaks of $\mathrm{CA}_{2}$ appeared at 19.90, 25.36, and $34.442-\theta$ degrees, which correspond to the interplanar spacing of $4.46 \AA$, $3.51 \AA$, and $2.60 \AA$, respectively. The measured chemical composition of the synthesized $\mathrm{CA}_{2}$ was $89.4 \mathrm{wt} . \%$ of $\mathrm{CA}_{2}$, 6.6 wt. $\%$ of $\mathrm{CA}_{6}$, and $2.5 \mathrm{wt} . \%$ of CA. Although pure $\mathrm{CA}_{2}$ was not synthesized, the $\mathrm{CA}_{2}$ was still expected to have a significant effect on the properties of the cement paste unlike $\mathrm{CA}$ or $\mathrm{CA}_{6}$. This will be discussed in detail when the phase composition of an anhydrous binder is addressed. Table 3 presents the oxide composition of the synthesized $\mathrm{CA}_{2}$, and Figure 5 shows the SEM image of the synthesized $\mathrm{CA}_{2}$. The SEM analysis verified that the grain size of $\mathrm{CA}_{2}$ was approximately $5 \mu \mathrm{m}$.

3.2. Phase Composition of Anhydrous Binder. Table 4 gives the composition ratio of the clinker in each binder. Figure 6 presents the same data in a bar graph. The clinker composition of cement was calculated by applying the oxide composition of cement to the Bogue equation [38]. The clinker composition ratio of $\mathrm{CD} 5$ and $\mathrm{CD} 10$ was calculated by considering the composition ratio of $\mathrm{CA}_{2}$ as calculated through the Rietveld analysis and using the mix ratio of the synthesized $\mathrm{CA}_{2}$ to the cement. As presented in Table 4, the ratio between $\mathrm{CA}_{6}$ and $\mathrm{CA}$ was calculated as $0.5 \mathrm{wt} \%$ in $\mathrm{CD} 5$ and 1.0 wt.\% in CD10; thus, the effect of $\mathrm{CA}_{6}$ and $\mathrm{CA}$ in each binder was expected to be minimal, while the effect of $\mathrm{CA}_{2}$ was expected to be significant.

\subsection{Chloride-Binding Capacity of Cement Paste Mixed with} Synthesized $\mathrm{CA}_{2}$. The bound chloride of the cement paste was calculated by subtracting the free chloride (as measured through the free chloride extraction test) from the total chloride. The bound chloride of the cement paste and free chloride results were curve-fitted by applying the Langmuir isotherm. A relationship between free chloride and bound

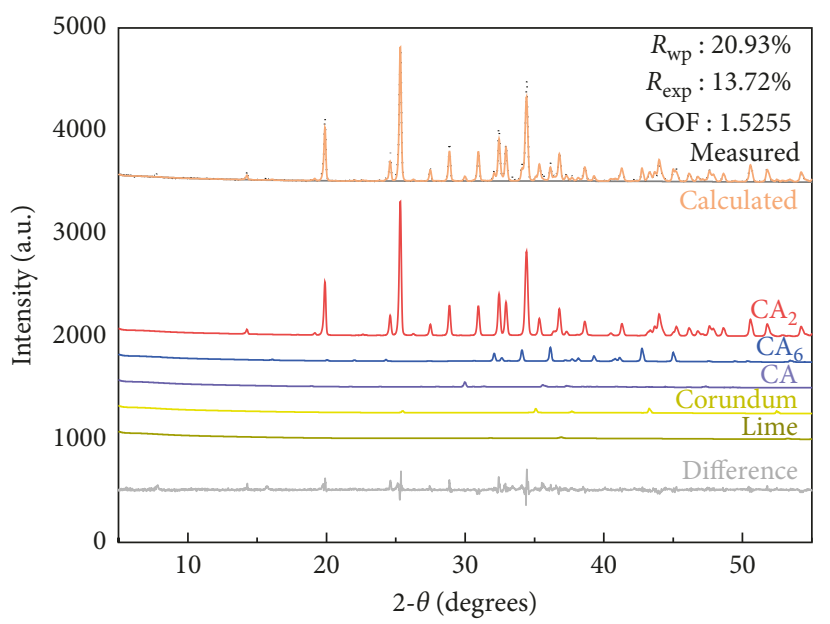

Figure 4: XRD pattern of synthesized $\mathrm{CA}_{2}$.

chloride was evaluated by the Langmuir or Freundlich isotherm in general $[17,26,39]$. However, as various hydrates from cement-based materials, which contain various minerals, have their own chloride-binding capacity (differing from each other), it was difficult to evaluate the chloridebinding capacity for the cement paste [17]. As the purpose of this experiment was only to approximate the chloride-binding capacity, only the Langmuir isotherm was applied. Figure 7 shows the relationship between bound chloride and free chloride, curve-fitted using the Langmuir isotherm. The Langmuir isotherm is expressed as follows:

$$
C_{\text {bound }}=\frac{\alpha \cdot C_{\text {free }}}{1+\beta \cdot C_{\text {free }}},
$$

where $C_{\text {bound }}$ is the bound chloride content and $C_{\text {free }}$ is the free chloride content; $\alpha$ and $\beta$ are the binding capacity constants.

As shown in Figure 7, the highest chloride-binding capacity was for CD10, followed by CD5 and PC. This indicates that the higher the content of $\mathrm{CA}_{2}$, the higher the 
TABLE 3: Oxide composition of synthesized $\mathrm{CA}_{2}$.

\begin{tabular}{lccccrr}
\hline Oxide composition (wt.\%) & $\mathrm{SiO}_{2}$ & $\mathrm{Al}_{2} \mathrm{O}_{3}$ & $\mathrm{Fe}_{2} \mathrm{O}_{3}$ & $\mathrm{CaO}$ & $\mathrm{Na}_{2} \mathrm{O}$ & $\mathrm{K}_{2} \mathrm{O}$ \\
\hline Synthesized $\mathrm{CA}_{2}$ & 0.12 & 74.87 & 0.04 & 24.37 & 0.40 & 0.01 \\
\hline
\end{tabular}

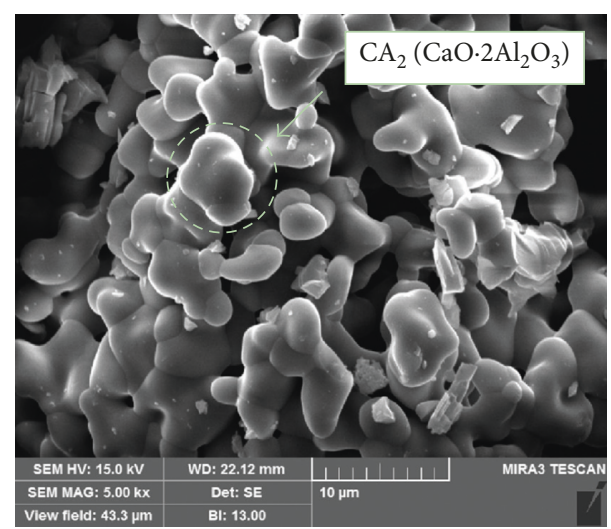

FIgURE 5: SEM image of synthesized $\mathrm{CA}_{2}$.

TABle 4: Phase composition of anhydrous binders.

\begin{tabular}{lcccccccc}
\hline \multirow{2}{*}{ Binder type } & \multicolumn{5}{c}{ Phase (wt.\%) } \\
& $\mathrm{C}_{3} \mathrm{~S}$ & $\mathrm{C}_{2} \mathrm{~S}$ & $\mathrm{C}_{3} \mathrm{~A}$ & $\mathrm{C}_{4} \mathrm{AF}$ & Amorphous, gypsum, calcite & $\mathrm{CA}_{2}$ & $\mathrm{CA}_{6}$ & $\mathrm{CA}$ \\
\hline PC & 57.10 & 11.60 & 8.70 & 8.60 & 14.0 & 0 & 0 \\
$\mathrm{CD} 5$ & 54.245 & 11.02 & 8.265 & 8.17 & 13.3 & 4.5 & 0.375 & 0.125 \\
$\mathrm{CD} 10$ & 51.39 & 10.44 & 7.83 & 7.74 & 12.6 & 9.0 & 0.75 & 0.25 \\
\hline
\end{tabular}

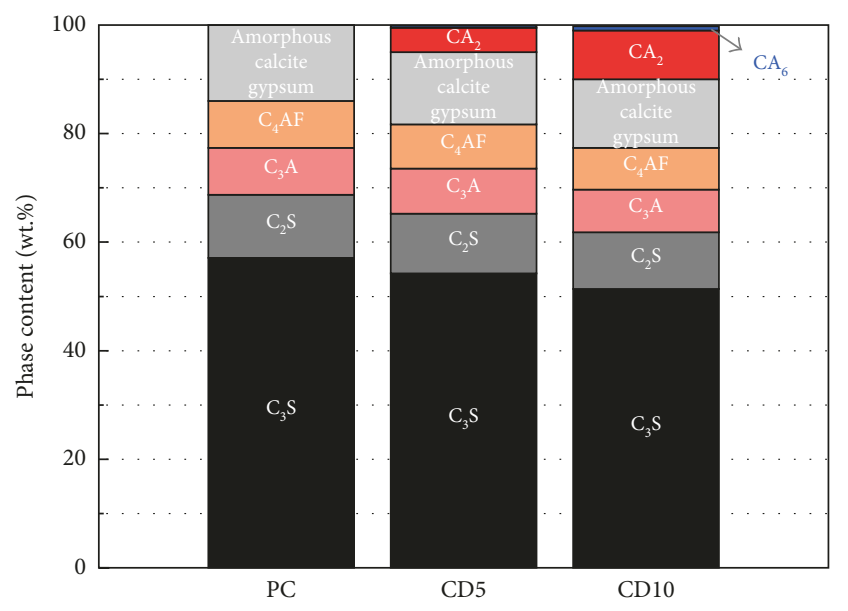

FIgURe 6: Phase composition of anhydrous PC, CD5, and CD10.

chloride-binding capacity. The effect of $\mathrm{CA}_{2}$ on chloridebinding capacity was similar to the effects of $\mathrm{C}_{3} \mathrm{~A}$, after the formation of the AFm phase in an environment with $\mathrm{Ca}$ $(\mathrm{OH})_{2}[33,40]$. The change rate of chloride-binding capacity was larger in $\mathrm{CD} 10 / \mathrm{CD} 5$ than $\mathrm{CD} 5 / \mathrm{PC}$. This indicates that the effect of $\mathrm{CA}_{2}$ on the binding of chloride ions was significant in an environment where chloride ions and $\mathrm{Ca}$ $(\mathrm{OH})_{2}$ were present. This will be discussed in detail in Sections 3.4 and 3.5 .

The blue dotted line in Figure 7 marks the result proposed in the study by Kim et al. [27] and indicates the result

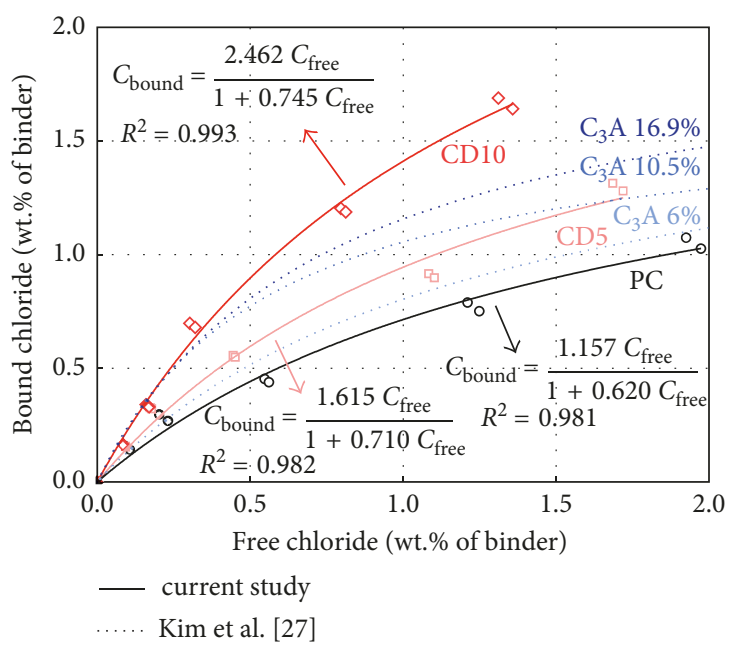

Figure 7: Chloride-binding capacity of PC, CD5, and CD10.

of chloride-binding capacity evaluated with the Langmuir isotherm according to the ratio of $\mathrm{C}_{3} \mathrm{~A}$ in a Portland cement paste. As this was obtained at 56 days of curing and the water-to-binder ratio was 0.4 (different from the present study results), it cannot be compared directly with the present experimental results. However, it implies that $\mathrm{CA}_{2}$ had a strong effect on the chloride-binding capacity of paste, similar to the effect of $\mathrm{C}_{3} \mathrm{~A}[40,41]$.

Figure 8 shows the percentage of bound chloride and free chloride under the total chloride (the sum of bound chloride 


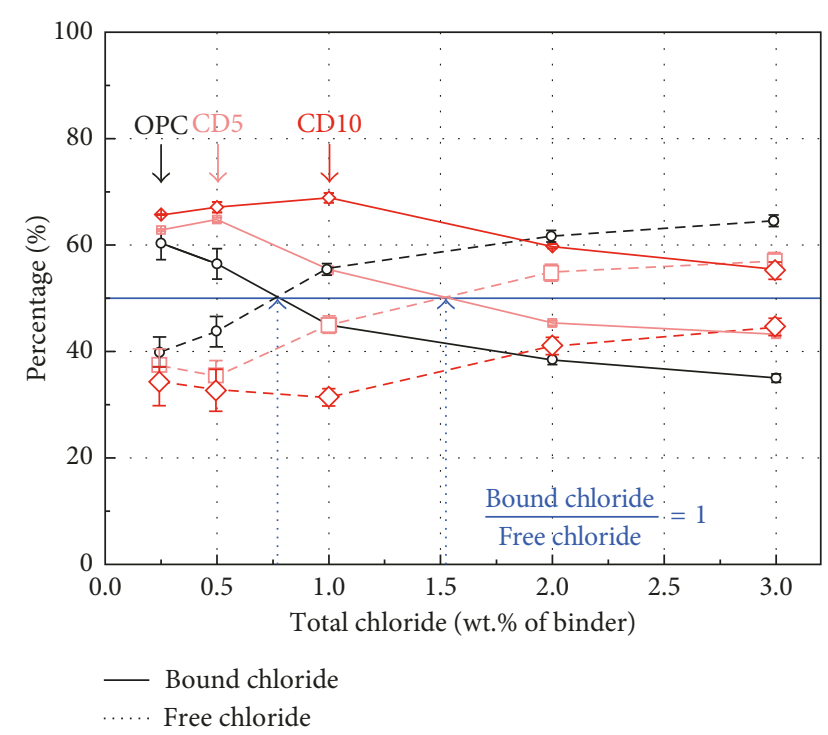

Figure 8: Percentage of bound chloride and free chloride according to total chloride.

and free chloride). As shown in Figure 8, the bound chloride of PC continued to decrease from a $0.25 \mathrm{wt} . \%$ total chloride; however, the bound chloride of CD5 increased up to $0.5 \mathrm{wt} . \%$, which subsequently decreased. The bound chloride of CD10 increased up to $1.0 \mathrm{wt} . \%$ and then decreased. The highest ratio of bound chloride to free chloride was for CD10 followed by CD5 and PC in all chloride conditions.

Bound chloride is a substance that is combined with chloride stably, even in an aqueous solution at $60^{\circ} \mathrm{C}$. Thus, an increase in the content ratio of $\mathrm{CA}_{2}$ facilitated the production of bound chloride in a chloride-enriched environment. The XRD and TGA results, which will be discussed later, exhibit the main composition of the bound chloride that existed in the synthesized $\mathrm{CA}_{2}$ /Portland cement paste.

3.4. XRD Patterns of Cement Paste Mixed with Synthesized $C A_{2}$. Prior to the verification of the effects of synthesized $\mathrm{CA}_{2}$ on chloride binding in a chloride environment, hydration reactions of $\mathrm{PC}, \mathrm{CD} 5$, and $\mathrm{CD} 10$ using only distilled water were conducted. Figure 9 presents the XRD patterns of PC, $\mathrm{CD} 5$, and CD10 as reacted with distilled water at 7 and 28 days.

As shown in Figure 9(a), all of PC, CD5, and CD10 showed the generation of $\mathrm{Ca}(\mathrm{OH})_{2}$ and a reduction in $\mathrm{C}_{3} \mathrm{~S}$ and $\mathrm{C}_{2} \mathrm{~S}$. However, a $\mathrm{CA}_{2}$ pattern was not revealed in $\mathrm{PC}$ and CD5 at 7 days of curing, whereas a weak basal peak of $\mathrm{CA}_{2}$ (in which hydration reaction was not complete) was verified in the XRD pattern of CD10. The basal peak of $\mathrm{CA}_{2}$ completely disappeared at 28 days. The hydration rate of $\mathrm{CA}_{2}$, in which $\mathrm{CaO} / \mathrm{Al}_{2} \mathrm{O}_{3}$ ratio was low, has been reported as low, but $\mathrm{CA}_{2}$ was completely dissolved after a few days [30].

As a pattern for $\mathrm{CA}_{2}$ was not observed at 28 days, it was assumed completely dissolved (as shown in Figure 9(a)). However, a previous study [30] proposed a situation, where only $\mathrm{CA}$ and $\mathrm{CA}_{2}$ were present, and further studies on the hydration of $\mathrm{CA}_{2}$ in the Portland cement-based system are required.

Figure 9(b) shows the enlarged graph of the XRD pattern between $5^{\circ}$ and $20^{\circ}$, which shows a clear difference in patterns between 7 and 28 days, and $10^{\circ}$ and $12^{\circ}$. The patterns of PC, CD5, and CD10 at 7 days did not show a clear peak between $10^{\circ}$ and $12^{\circ}$; however, their patterns at 28 days showed a basal peak between $10.5^{\circ}$ and $11.5^{\circ}$. The peak revealed between $10.7^{\circ}$ and $11.5^{\circ}$ was considered the basal peak of the AFm phase, which revealed a tiny shift between $10^{\circ}$ and $12^{\circ}$ according to the anion type in the interlayer $\left(\mathrm{OH}^{-}, \mathrm{SO}_{4}{ }^{2-}, \mathrm{CO}_{3}{ }^{2-}\right.$, and $\left.\mathrm{Cl}^{-}\right)[19,20,23,28]$.

Figure 9 shows the cement paste using distilled water, so an AFm phase mixed with $\mathrm{OH}^{-}, \mathrm{SO}_{4}{ }^{2-}$, and $\mathrm{CO}_{3}{ }^{2-}$ at the interlayer was expected to be generated instead of chloride-AFm (Cl-AFm). The generation of $\mathrm{OH}-\mathrm{AFm}, \mathrm{SO}_{4}-\mathrm{AFm}$, and $\mathrm{CO}_{3}{ }^{-}$ AFm was determined by a comparison of the interplanar spacing of basal peaks amongst our XRD results as compared to those of existing study results $[20,28]$. A peak at $11.5^{\circ}$, with an interplanar spacing of approximately $7.6 \AA$, was seen for PC, CD5, and CD10 at 28 days and was considered the monocarboaluminate peak. Furthermore, a peak at $10.7^{\circ}$, with an interplanar spacing of about $8.2 \AA$, was found in CD5 and CD10 at 28 days, which was determined to be the hemicarboaluminate peak.

Carbonation, which possibly occurred in the process of making cement paste power, could create mainly $\mathrm{CO}_{3}-\mathrm{AFm}$. As mentioned above, a wide and continuous basal peak was seen (versus a well-defined peak). $\mathrm{OH}^{-}, \mathrm{SO}_{4}{ }^{2-}$, and $\mathrm{CO}_{3}{ }^{2-}$ were seen to have an effect on the interlayer of the AFm phase complex. Without the carbonation effect, mainly $\mathrm{OH}$ AFm was expected to be generated $[10,31,32]$.

It was clear that the relative intensity of the main AFm phase peak was stronger at 28 days for CD5 and CD10 than for PC (as shown in Figure 9(b)). However, since no quantitative analysis was conducted using standard components, a change during the generation of the AFm phase cannot be deduced, but analyzed comprehensively using the TGA results. This will be discussed in Section 3.5. As the AFm phase was metastable, a phase change might occur according to the surrounding anion environment (as shown in Figure 9(b)), and the changes in the AFm phase could be verified by the XRD results.

Figure 10(a) shows the XRD patterns of PC, CD5, and CD10 binders, which were reacted with distilled water or chloride solution at 28 days. Figures 9(a) and 9(b) show an enlarged view of the main boundary from Figure 10(a) to compare the main peaks of $\mathrm{Ca}(\mathrm{OH})_{2}$ and the AFm phase. Figure 10(b) shows the difference between the AFm phase of PC, CD5, and CD10 using distilled water and chloride solution.

The AFm phase peak of PC, CD5, and CD10 mixed with distilled water was seen weakly between $10.7^{\circ}$ and $11.5^{\circ}$, whereas the AFm phase peak of PC, CD5, and CD10 mixed with $1 \%$ and $3 \%$ chloride solution was seen strongly around $11^{\circ}$. The peak at $11^{\circ}$ was verified as the main peak of $\mathrm{Cl}-\mathrm{AFm}$, which had a stronger relative intensity with the $3 \%$ chloride solution than the one with the $1 \%$ chloride solution. The highest relative intensity of Cl-AFm was for CD10, followed by CD5 and PC.

The synthesized $\mathrm{CA}_{2}$ was investigated to facilitate a formation of $\mathrm{Cl}-\mathrm{AFm}$ in the Portland cement-based system. More specifically, the analysis showed that the type of Cl-AFm can vary according to the ratio of anion in the surrounding environment. In the Portland cement system, when sulfate is present, Kuzel's salt mixed with $\mathrm{Cl}^{-}$and $\mathrm{SO}_{4}{ }^{2-}$ is typically seen 


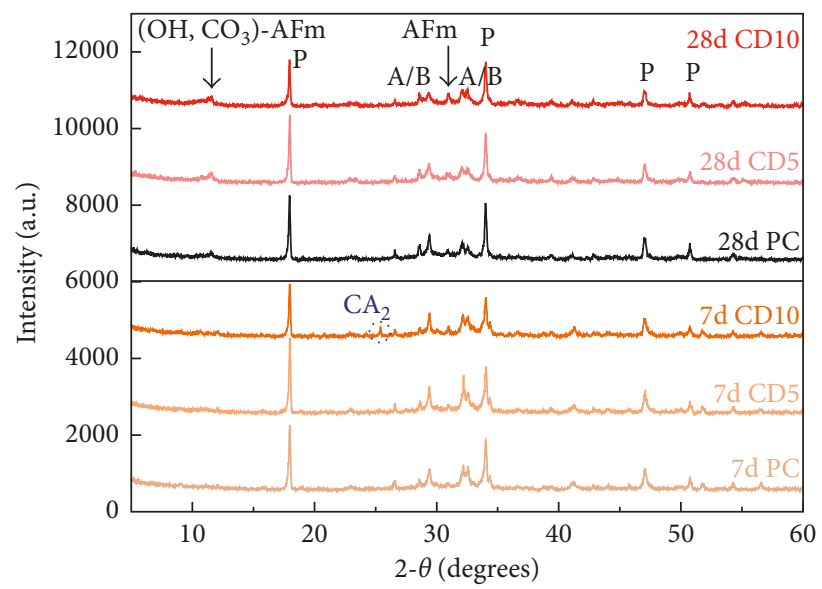

(a)

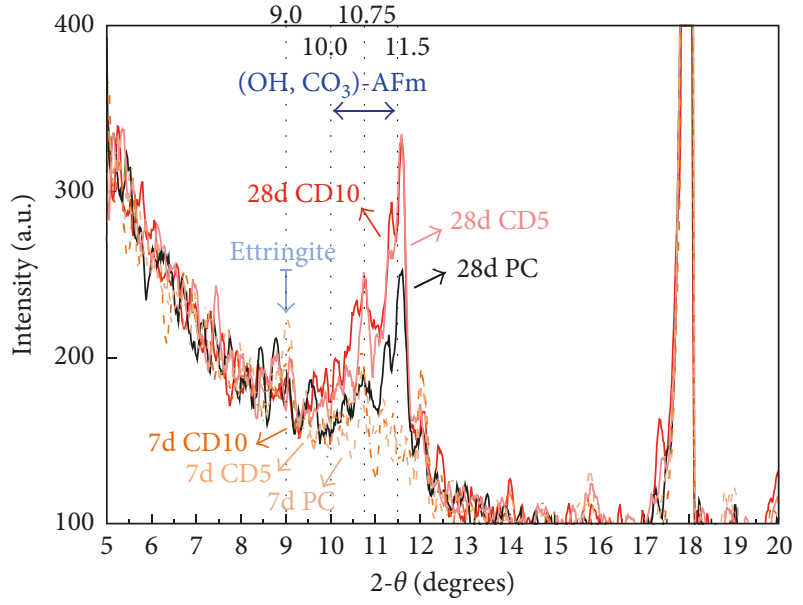

(b)

Figure 9: XRD patterns of PC, CD5, and CD10 reacted with distilled water at 7 and 28 days. (a) The XRD patterns between $5^{\circ}$ and $60^{\circ}$. (b) The XRD patterns between $5^{\circ}$ and $20^{\circ} ; \mathrm{P}: \mathrm{Ca}(\mathrm{OH})_{2}, \mathrm{~A} / \mathrm{B}: \mathrm{C}_{3} \mathrm{~S}$ and $\mathrm{C}_{2} \mathrm{~S}$, and $\mathrm{AFm}$ : AFm phases.

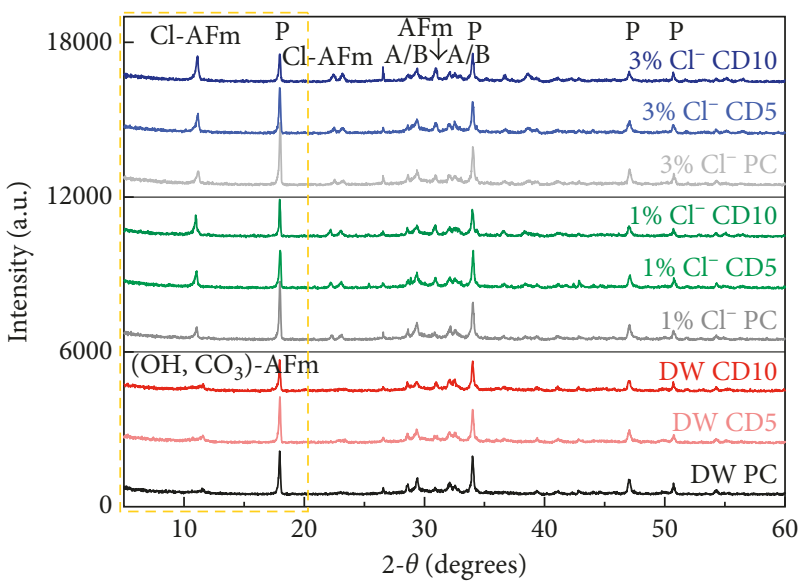

(a)

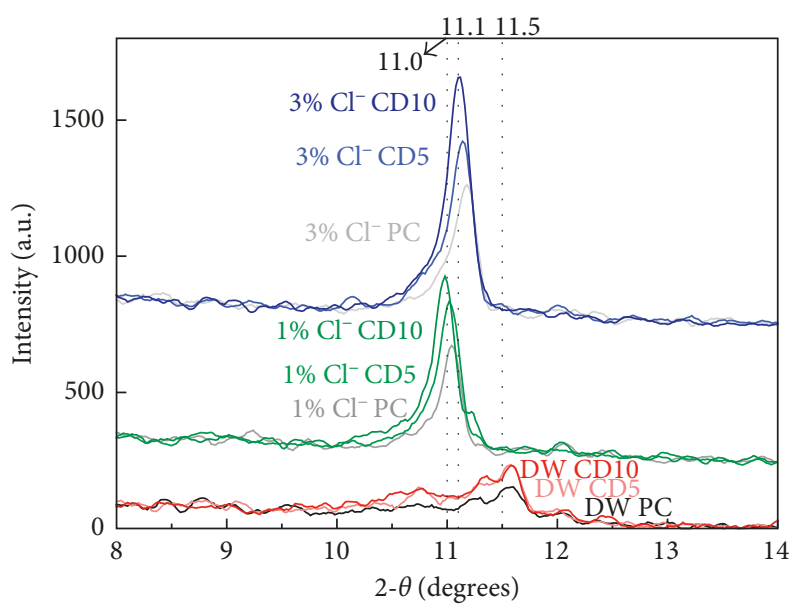

(b)

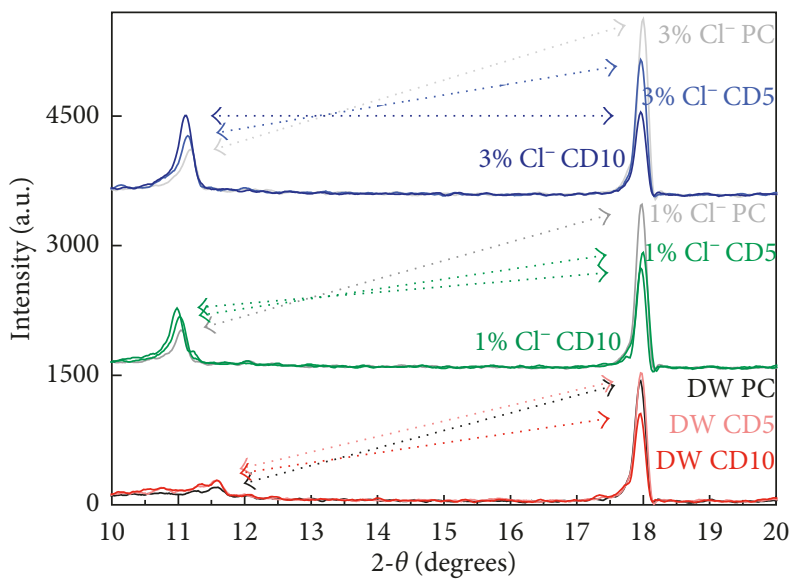

(c)

Figure 10: XRD patterns of PC, CD5, and CD10 reacted with distilled water or chloride solution at 28 days. (a) The XRD patterns between $5^{\circ}$ and $60^{\circ}$. (b) The XRD patterns between $8^{\circ}$ and $14^{\circ}$. (c) The XRD patterns between $10^{\circ}$ and $20^{\circ} ; \mathrm{P}: \mathrm{Ca}(\mathrm{OH})_{2}, \mathrm{~A} / \mathrm{B}: \mathrm{C}_{3} \mathrm{~S}$ and $\mathrm{C}_{2} \mathrm{~S}$, and $\mathrm{AFm}$ : AFm phases. 

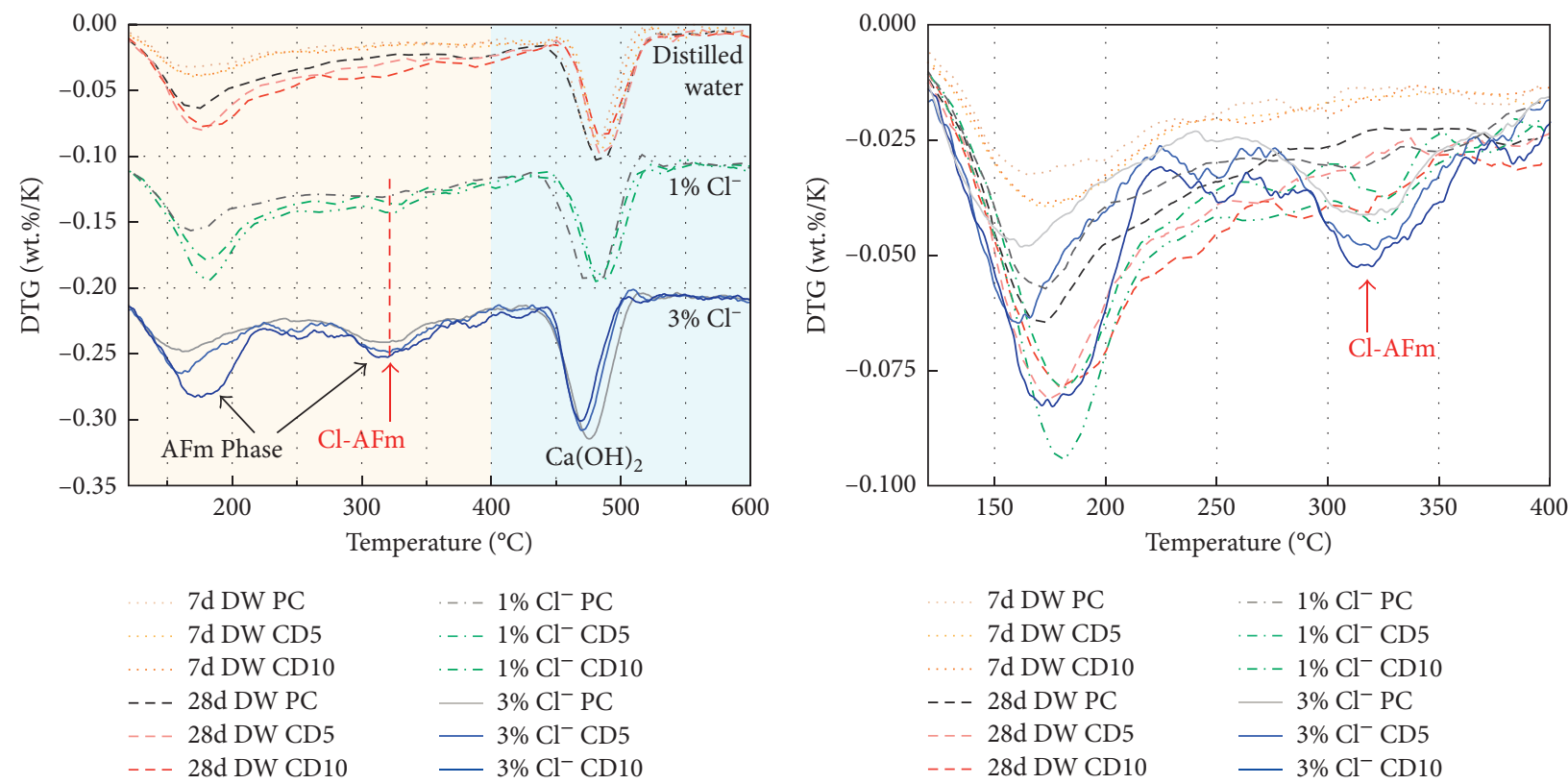

(a)

(b)

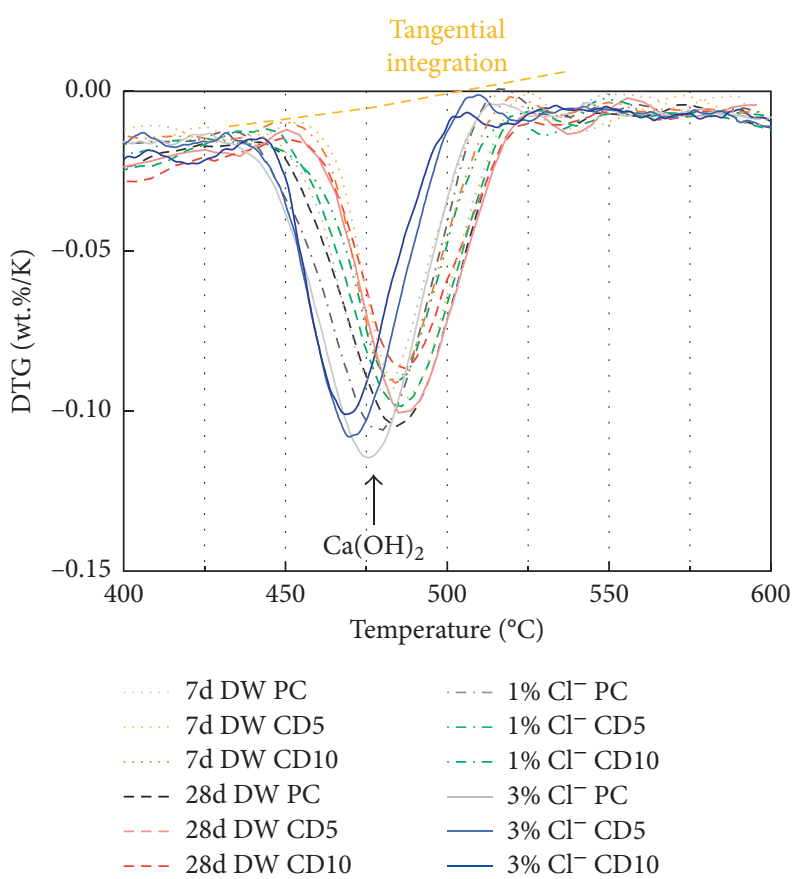

(c)

FIGURE 11: TGA results of PC, CD5, and CD10 reacted with distilled water and chloride solution. (a) The DTG curve between $120^{\circ} \mathrm{C}$ and $600^{\circ} \mathrm{C}$ (offset); (b) the DTG curve between $120^{\circ} \mathrm{C}$ and $400^{\circ} \mathrm{C}$; (c) the DTG curve between $400^{\circ} \mathrm{C}$ and $600^{\circ} \mathrm{C}$.

in the interlayer of the AFm phase $[19,22,28,42]$. Additionally, $\mathrm{Cl}$-AFm is affected by $\mathrm{OH}^{-}$and $\mathrm{CO}_{3}{ }^{2-}$ such that a shift in a basal peak may be exhibited $[19,43]$. The XRD peak with the $1 \%$ chloride solution was shifted more to the left than with the $3 \%$ chloride solution (from $11.1^{\circ}$ to $11.0^{\circ}$, as shown in Figure 10(b)) due to the effect of $\mathrm{CO}_{3}{ }^{2-}, \mathrm{SO}_{4}{ }^{2-}$, and $\mathrm{OH}^{-}$.

Figure 10 (c) shows a relative intensity of the major peak between the $\mathrm{AFm}$ phase and $\mathrm{Ca}(\mathrm{OH})_{2}$. The relative ratios of the
$\mathrm{XRD}$ peaks equalize in the following order: $\mathrm{CD} 10>\mathrm{CD} 5>\mathrm{PC}$. The relative ratios of the peaks became equal where the chloride ion concentration of the mixing water was high. The reduction in a relative intensity of the $\mathrm{Ca}(\mathrm{OH})_{2}$ major peak was due to the replacement of some cement with synthesized $\mathrm{CA}_{2}$, thereby decreasing the amount of generated $\mathrm{Ca}(\mathrm{OH})_{2}$ [32]. This was because $\mathrm{CD} 5$ and $\mathrm{CD} 10$ generated more $\mathrm{Cl}-\mathrm{AFm}$ phase than $\mathrm{PC}$. This can be verified through TGA. 
3.5. TGA Results of Cement Paste Mixed with Synthesized $C A_{2}$. Figure 11 presents the TGA results for PC, CD5, and $\mathrm{CD} 10$, when reacted with distilled water or chloride solution. The differential thermogravimetric (DTG) curve was normalized to final mass [44].

Figure 11(a) shows the DTG curve (offset) of each binder with various aqueous solutions. In general, the DTG curve of all types of the AFm phase revealed a similar peak. It has been reported that the DTG curve of pure Friedel's salt or Kuzel's salt showed that dehydration of the interlayer water was exhibited first between $100^{\circ} \mathrm{C}$ and $200^{\circ} \mathrm{C}$, and then, dehydroxylation of the main layer water was seen between $200^{\circ} \mathrm{C}$ and $400^{\circ} \mathrm{C}[41,42,45,46]$. With the same aqueous solution, the mass reduction of CD5 and CD10 was larger than that of PC between $120^{\circ} \mathrm{C}$ and $400^{\circ} \mathrm{C}$. The mass reduction of $3 \% \mathrm{Cl}^{-} \mathrm{PC}, \mathrm{CD} 5$, and $\mathrm{CD} 10$ (which had the highest chloride ion concentration) was the largest between $250^{\circ} \mathrm{C}$ and $350^{\circ} \mathrm{C}$.

CD5 and CD10 were expected to have less generation of C-(A)-S-H than PC due to the reduction in $\mathrm{C}_{3} \mathrm{~S}$ and $\mathrm{C}_{2} \mathrm{~S}$ $[44,47]$, so the DTG peak for CD5 and CD10 between $120^{\circ} \mathrm{C}$ and $250^{\circ} \mathrm{C}$ was expected to be smaller than that of PC, but the opposite result was exhibited. This was due to the increase in the AFm phase generation in CD5 and CD10, where relatively more AFm phase was formed due to the synthesized $\mathrm{CA}_{2}$ mixed in the cement. For more detailed analysis, an offset of the DTG curve was removed.

Figure $11(\mathrm{~b})$ shows the DTG curve between $120^{\circ} \mathrm{C}$ and $400^{\circ} \mathrm{C}$ without an offset. The change in mass reduction between $250^{\circ} \mathrm{C}$ and $350^{\circ} \mathrm{C}$ was more rapid in a more highly concentrated chloride aqueous solution, whereas the change in mass reduction between $120^{\circ} \mathrm{C}$ and $250^{\circ} \mathrm{C}$ did not exhibit a change due to the concentration of chloride. The change in mass reduction with a $1 \%$ chloride solution between $120^{\circ} \mathrm{C}$ and $250^{\circ} \mathrm{C}$ was larger than that of the $3 \%$ chloride solution. The major reason is due to the chemical composition of the interlayer in the AFm phase, although dehydration of various cement hydrates may have affected this as well [44]. The reason for the higher change in mass reduction between $120^{\circ} \mathrm{C}$ and $250^{\circ} \mathrm{C}$ in a $1 \%$ chloride solution versus the $3 \%$ chloride solution is due to the higher ratio of water molecules, $\mathrm{OH}^{-}$, and $\mathrm{SO}_{4}{ }^{2-}$ that existed along with the $\mathrm{Cl}^{-}$at the interlayer as mentioned in the XRD results.

Figure $11(\mathrm{c})$ shows the DTG curve between $400^{\circ} \mathrm{C}$ and $600^{\circ} \mathrm{C}$ without an offset and is displayed to calculate the $\mathrm{Ca}$ $(\mathrm{OH})_{2}$ content generated in PC, CD5, and CD10 for each aqueous solution. The peak shown between $400^{\circ} \mathrm{C}$ and $600^{\circ} \mathrm{C}$ was due to the dehydroxylation of $\mathrm{Ca}(\mathrm{OH})_{2}$. There was the shift of the peak to a lower temperature in high concentrations of chloride solution because chloride inhibits the hydrogen bond of $\mathrm{Ca}(\mathrm{OH})_{2}$ [48]. The $\mathrm{Ca}(\mathrm{OH})_{2}$ content was calculated using integration of the DTG peak for $\mathrm{Ca}(\mathrm{OH})_{2}$, and a tangential integration method was employed [44, 49].

Table 5 presents the $\mathrm{Ca}(\mathrm{OH})_{2}$ content of $\mathrm{PC}, \mathrm{CD} 5$, and $\mathrm{CD} 10$ for each aqueous solution. Overall, the $\mathrm{Ca}(\mathrm{OH})_{2}$ tended towards higher generation with a higher chloride concentration because $\mathrm{NaCl}$ mixed in the water facilitated dissolution of $\mathrm{C}_{3} \mathrm{~S}$ [50]. It is important that the production of $\mathrm{Ca}(\mathrm{OH})_{2}$ was noticeably reduced according to the increase
TABle 5: $\mathrm{Ca}(\mathrm{OH})_{2}$ content of PC, $\mathrm{CD} 5$, and $\mathrm{CD} 10$ at 28 days.

\begin{tabular}{lccr}
\hline \multirow{2}{*}{ Binder type } & \multicolumn{3}{c}{$\mathrm{Ca}(\mathrm{OH})_{2}$ content (wt.\% of binder) } \\
& $\mathrm{DW}$ & $1 \% \mathrm{Cl}^{-}$ & $3 \% \mathrm{Cl}^{-}$ \\
\hline PC & 15.23 & 15.94 & 16.34 \\
$\mathrm{CD} 5$ & 12.90 & 13.80 & 13.75 \\
$\mathrm{CD} 10$ & 10.32 & 10.49 & 10.74 \\
\hline \multicolumn{3}{c}{ Ratio of $\mathrm{Ca}(\mathrm{OH})_{2}$ content } \\
& $\mathrm{DW}$ & $1 \% \mathrm{Cl}^{-}$ & $3 \% \mathrm{Cl}^{-}$ \\
\hline $\mathrm{CD} 5 / \mathrm{PC}$ & 0.847 & 0.865 & 0.841 \\
$\mathrm{CD} 10 / \mathrm{PC}$ & 0.677 & 0.658 & 0.657 \\
\hline
\end{tabular}

in the content ratio of synthesized $\mathrm{CA}_{2}$ for the Portland cement system. The ratio of $\mathrm{Ca}(\mathrm{OH})_{2}$ generated in $\mathrm{CD} 5$ and $\mathrm{CD} 10$ was about 0.85 and 0.66 of $\mathrm{PC}$, respectively. The main reason for this was the effective replacement of cement with $\mathrm{CA}_{2}$, which contributes to $\mathrm{Ca}(\mathrm{OH})_{2}$ generation. Furthermore, $\mathrm{Ca}(\mathrm{OH})_{2}$ may be consumed due to the formation of $\mathrm{OH}-\mathrm{AFm}$ coming from the reaction of $\mathrm{CA}_{2}$ with $\mathrm{Ca}(\mathrm{OH})_{2}$ [33]. The low $\mathrm{pH}$ environment from the increase of $\mathrm{CA}_{2}$ (in which ratio of aluminum oxide was high in the $\mathrm{PC}$ system) increased the dissolution of $\mathrm{Ca}(\mathrm{OH})_{2}$ to some extent [11].

It was conclusive that although the ratio of C-(A)-S-H and $\mathrm{Ca}(\mathrm{OH})_{2}$ reduced as the ratio of $\mathrm{PC}$ reduced, the highest chloride-binding capacity in CD10 was attributed mainly to the generation of the AFm phase. This result is consistent with exiting studies in which the AFm phase played a more important role than C-(A)-S-H and $\mathrm{Ca}(\mathrm{OH})_{2}$ in terms of chloride-binding capacity in the paste [17].

\section{Conclusions}

This study examined the effects of $\mathrm{CA}_{2}$ on the chloride-binding capacity of the Portland cement-based systems. And it is concluded that the synthesized $\mathrm{CA}_{2}$ contributes to the formation of the AFm phase in Portland cement paste, and $\mathrm{CA}_{2}$ plays an important role in the improvement of chloride-binding capacity in the synthesized $\mathrm{CA}_{2}$ /Portland cement systems. The aforementioned results are summarized as follows:

(1) Experiments were conducted using internal chloride to evaluate the chloride-binding capacity of a synthesized $\mathrm{CA}_{2} /$ Portland cement paste. The bound chloride content was estimated using the Langmuir isotherm, and $\mathrm{CA}_{2}$ was determined to have significantly increased the chloride-binding capacity in the paste. In particular, the ratio between a bound chloride and a total chloride continued to increase with higher concentrations of chloride solution in the order $\mathrm{CD} 10>\mathrm{CD} 5>\mathrm{PC}$. This indicates that the synthesized $\mathrm{CA}_{2}$ increases the chloride-binding efficiency of the paste.

(2) The formation of $\mathrm{Cl}-\mathrm{AFm}$ in $1 \%$ and $3 \%$ chloride solutions was in the order $\mathrm{CD} 10>\mathrm{CD} 5>\mathrm{PC}$, and the results showed that as the chloride concentration became higher, the production of $\mathrm{Cl}-\mathrm{AFm}$ increased. Furthermore, the major effect of $\mathrm{OH}^{-}, \mathrm{SO}_{4}{ }^{2-}, \mathrm{CO}_{3}{ }^{2-}$, and/or water molecules (other than $\mathrm{Cl}^{-}$) in the $\mathrm{Cl}$ AFm interlayer composition was recognized. 
(3) The effect of synthesized $\mathrm{CA}_{2}$ on chloride binding for the Portland cement-based systems was observed using XRD and TGA. As the cement was replaced with synthesized $\mathrm{CA}_{2}$, the generation of $\mathrm{Ca}(\mathrm{OH})_{2}$ was decreased, while the generation of the AFm phase was increased at 28 days. As a result, it was concluded that $\mathrm{CA}_{2}$ contributes to the formation of AFm, which has higher chloride-binding capacity than $\mathrm{Ca}(\mathrm{OH})_{2}$. But the contribution was smaller in distilled water rather than chloride solutions.

\section{Conflicts of Interest}

The authors declare no conflicts of interest.

\section{Authors' Contributions}

Yunsu Lee performed the experiments and wrote the paper. Mingyun Kim and Zhengxin Chen contributed to the preparation of experiments. Hanseung Lee and Seungmin Lim contributed to reviewing the discussion of the paper.

\section{Acknowledgments}

This research was supported by a grant (17SCIP-B103706-03) from the Construction Technology Research Program funded by the Ministry of Land, Infrastructure and Transport of the Korean government.

\section{References}

[1] H. F. Taylor, Cement Chemistry, Thomas Telford Publishing, London, UK, 2nd edition, 1997.

[2] W. Kurdowski, Cement and Concrete Chemistry, Springer Science \& Business, New York, NY, USA, 2014.

[3] K. L. Scrivener, J. L. Cabiron, and R. Letourneux, "Highperformance concretes from calcium aluminate cements," Cement and Concrete Research, vol. 29, no. 8, pp. 1215-1223, 1999.

[4] M. Juenger, F. Winnefeld, J. L. Provis, and J. Ideker, "Advances in alternative cementitious binders," Cement and Concrete Research, vol. 41, no. 12, pp. 1232-1243, 2011.

[5] P. Barnes and J. Bensted, Structure and Performance of Cements, Spon Press, New York, NY, USA, 2nd edition, 2002.

[6] J. Bizzozero, "Hydration and dimensional stability of calcium aluminate cement based systems," Ph.D. thesis, Ecole Polytechnique Fédérale de Lausanne, Lausanne, Switzerland, 2014.

[7] P. Garcés, E. G. Alcocel, S. Chinchón, C. G. Andreu, and J. Alcaide, "Effect of curing temperature in some hydration characteristics of calcium aluminate cement compared with those of Portland cement," Cement and concrete research, vol. 27, no. 9, pp. 1343-1355, 1997.

[8] Ö. Kırca, İ. Ö. Yaman, and M. Tokyay, "Compressive strength development of calcium aluminate cement-GGBFS blends," Cement and Concrete Composites, vol. 35, no. 1, pp. 163-170, 2013.

[9] C. Gosselin, "Microstructural development of calcium aluminate cement based systems with and without supplementary cementitious materials," Ph.D. thesis, Ecole Polytechnique Fédérale de Lausanne, Lausanne, Switzerland, 2009.

[10] L. Xu, P. Wang, G. De Schutter, and G. Wu, "Effect of calcium aluminate cement variety on the hydration of Portland cement in blended system," Journal of Wuhan University of Technology-Mater Sci. Ed., vol. 29, no. 4, pp. 751-756, 2014.
[11] K. Ann, T.-S. Kim, J. Kim, and S.-H. Kim, "The resistance of high alumina cement against corrosion of steel in concrete," Construction and Building Materials, vol. 24, no. 8, pp. 15021510, 2010.

[12] L. Fernández-Carrasco and E. Vázquez, "Reactions of fly ash with calcium aluminate cement and calcium sulphate," Fuel, vol. 88, no. 9, pp. 1533-1538, 2009.

[13] M. Alonso, J. Vera-Agullo, L. Guerreiro, V. Flor-Laguna, M. Sanchez, and M. Collares-Pereira, "Calcium aluminate based cement for concrete to be used as thermal energy storage in solar thermal electricity plants," Cement and Concrete Research, vol. 82, pp. 74-86, 2016.

[14] G. Falzone, M. Balonis, and G. Sant, "X-AFm stabilization as a mechanism of bypassing conversion phenomena in calcium aluminate cements," Cement and Concrete Research, vol. 72, pp. 54-68, 2015.

[15] Ö. Kirca, "Temperature effect on calcium aluminate cement based composite binders," Ph.D. thesis, Middle East Technical University, Ankara, Turkey, 2006.

[16] T.-H. Ahn, K.-B. Shim, K.-H. So, and J.-S. Ryou, "Influence of lead and chromium ions as toxic heavy metals between $\mathrm{AFt}$ and $\mathrm{AFm}$ phases based on $\mathrm{C}_{3} \mathrm{~A}$ and $\mathrm{C}_{4} \mathrm{~A}_{3}$," Journal of Ceramic Processing Research, vol. 15, no. 6, pp. 539-544, 2014.

[17] M. Florea and H. Brouwers, "Chloride binding related to hydration products: Part I: ordinary Portland cement," Cement and Concrete Research, vol. 42, no. 2, pp. 282-290, 2012.

[18] V. Rives and M. A. Ulibarri, "Layered double hydroxides (LDH) intercalated with metal coordination compounds and oxometalates," Coordination Chemistry Reviews, vol. 181, no. 1, pp. 61-120, 1999.

[19] M. Balonis, B. Lothenbach, G. Le Saout, and F. P. Glasser, "Impact of chloride on the mineralogy of hydrated Portland cement systems," Cement and Concrete Research, vol. 40, no. 7, pp. 1009-1022, 2010.

[20] T. Matschei, B. Lothenbach, and F. Glasser, "The AFm phase in Portland cement," Cement and Concrete Research, vol. 37, no. 2, pp. 118-130, 2007.

[21] L. Raki, J. Beaudoin, and L. Mitchell, "Layered double hydroxidelike materials: nanocomposites for use in concrete," Cement and Concrete Research, vol. 34, no. 9, pp. 1717-1724, 2004.

[22] S. Yoon, J. Ha, S. R. Chae et al., "Phase changes of monosulfoaluminate in $\mathrm{NaCl}$ aqueous solution," Materials, vol. 9, no. 12, p. 401, 2016.

[23] G. Puerta-Falla, M. Balonis, G. Falzone, M. Bauchy, N. Neithalath, and G. Sant, "Monovalent ion exchange kinetics of hydrated calcium-alumino layered double hydroxides," Industrial \& Engineering Chemistry Research, vol. 56, no. 1, pp. 63-74, 2016.

[24] B. Martın-Pérez, H. Zibara, R. Hooton, and M. Thomas, "A study of the effect of chloride binding on service life predictions," Cement and Concrete Research, vol. 30, no. 8, pp. 1215-1223, 2000.

[25] Q. Yuan, C. Shi, G. De Schutter, K. Audenaert, and D. Deng, "Chloride binding of cement-based materials subjected to external chloride environment-a review," Construction and Building Materials, vol. 23, no. 1, pp. 1-13, 2009.

[26] H. Hirao, K. Yamada, H. Takahashi, and H. Zibara, "Chloride binding of cement estimated by binding isotherms of hydrates," Journal of Advanced Concrete Technology, vol. 3, no. 1, pp. 77-84, 2005.

[27] M. J. Kim, K. B. Kim, and K. Y. Ann, "The influence of $C_{3} A$ content in cement on the chloride transport," Advances in Materials Science and Engineering, vol. 2016, Article ID 5962821, 8 pages, 2016.

[28] A. Mesbah, C. Caudit-Coumes, G. Renaudin, F. Frizon, and F. Leroux, "Uptake of chloride and carbonate ions by calcium 
monosulfoaluminate hydrate," Cement and Concrete Research, vol. 42, no. 8, pp. 1157-1165, 2012.

[29] M. Batog and Z. Giergiczny, "Influence of mass concrete constituents on its properties," Construction and Building Materials, vol. 146, pp. 221-230, 2017.

[30] S. Klaus, J. Neubauer, and F. Goetz-Neunhoeffer, "Hydration kinetics of $\mathrm{CA}_{2}$ and $\mathrm{CA}$-investigations performed on a synthetic calcium aluminate cement," Cement and Concrete Research, vol. 43, pp. 62-69, 2013.

[31] K. Tabara, K. Miyaguchi, M. Morioka, and K. Takewaka, "Hydration behavior and fixation ability of chloride ion by a variety of kinds of hardened cements added with $\mathrm{CaO} \cdot 2 \mathrm{Al}_{2} \mathrm{O}_{3}$," Cement Science and Concrete Technology, vol. 65, no. 1, pp. 427-434, 2011.

[32] K. Tabara, K. Yamamoto, M. Ashida, and M. Morioka, "Fixation ability of chloride ion by hardened cement added with $\mathrm{CaO} \cdot 2 \mathrm{Al}_{2} \mathrm{O}_{3}$," Cement Science and Concrete Technology, vol. 66, no. 1, pp. 491-498, 2013.

[33] T. Mori, Y. Ishii, K. Tabara, and M. Morioka, "Influence of sintering temperature on synthesis of $\mathrm{CaO} \cdot(2-\mathrm{n}) \mathrm{Al}_{2} \mathrm{O}_{3} \cdot \mathrm{nFe}_{2} \mathrm{O}_{3}$ complete solid solution compounds," Cement Science and Concrete Technology, vol. 70, no. 1, pp. 85-90, 2017.

[34] A. Tchamba, J. Sofack, R. Yongue, and U. Melo, "Formulation of calcium dialuminate $\left(\mathrm{CaO} \cdot 2 \mathrm{Al}_{2} \mathrm{O}_{3}\right)$ refractory cement from local bauxite," Journal of Asian Ceramic Societies, vol. 3, no. 2, pp. 164-172, 2015.

[35] ASTM C1218/C1218M-17, Standard Test Method for Water-Soluble Chloride in Mortar and Concrete, ASTM International, West Conshohocken, PA, USA, http://www.astm.org, 2017.

[36] C. Arya, N. Buenfeld, and J. Newman, "Assessment of simple methods of determining the free chloride ion content of cement paste," Cement and Concrete Research, vol. 17, no. 6, pp. 907-918, 1987.

[37] C. Arya and J. Newman, "An assessment of four methods of determining the free chloride content of concrete," Materials and Structures, vol. 23, no. 5, pp. 319-330, 1990.

[38] R. Sam, S. Bamford, J. Fletcher, F. Ofosu, and A. Fuseini, "Assessment of quality of the various brands of Portland cement products available on the Ghanaian market," International Journal of Science and Technology, vol. 2, no. 3, pp. 252-258, 2013.

[39] T. Luping and L.-O. Nilsson, "Chloride binding capacity and binding isotherms of OPC pastes and mortars," Cement and Concrete Research, vol. 23, no. 2, pp. 247-253, 1993.

[40] A. Suryavanshi, J. Scantlebury, and S. Lyon, "Mechanism of Friedel's salt formation in cements rich in tri-calcium aluminate," Cement and Concrete Research, vol. 26, no. 5, pp. 717-727, 1996.

[41] U. Birnin-Yauri and F. Glasser, "Friedel's salt, $\mathrm{Ca}_{2} \mathrm{Al}(\mathrm{OH})_{6}(\mathrm{Cl}$, $\mathrm{OH}) \cdot 2 \mathrm{H}_{2} \mathrm{O}$ : its solid solutions and their role in chloride binding," Cement and Concrete Research, vol. 28, no. 12, pp. 1713-1723, 1998.

[42] A. Mesbah, M. François, C. Caudit-Coumes et al., "Crystal structure of Kuzel's salt $3 \mathrm{CaO} \cdot \mathrm{Al}_{2} \mathrm{O}_{3} \cdot 1 / 2 \mathrm{CaSO}_{4} \cdot 1 / 2 \mathrm{CaCl}_{2} \cdot 11 \mathrm{H}_{2} \mathrm{O}$ determined by synchrotron powder diffraction," Cement and Concrete Research, vol. 41, no. 5, pp. 504-509, 2011.

[43] A. Mesbah, C. Caudit-Coumes, F. Frizon, F. Leroux, J. Ravaux, and G. Renaudin, "A new investigation of the $\mathrm{Cl}^{-}-\mathrm{CO}_{3}{ }^{2-}$ substitution in AFm phases," Journal of the American Ceramic Society, vol. 94, no. 6, pp. 1901-1910, 2011.

[44] K. Scrivener, R. Snellings, and B. Lothenbach, A Practical Guide to Microstructural Analysis of Cementitious Materials, CRC Press, Boca Raton, FL, USA, 2016.

[45] R. O. Grishchenko, A. L. Emelina, and P. Y. Makarov, "Thermodynamic properties and thermal behavior of Friedel's salt," Thermochimica acta, vol. 570, pp. 74-79, 2013.
[46] Z. Shi, M. R. Geiker, B. Lothenbach et al., "Friedel's salt profiles from thermogravimetric analysis and thermodynamic modelling of Portland cement-based mortars exposed to sodium chloride solution," Cement and Concrete Composites, vol. 78, pp. 73-83, 2017.

[47] E. T. Rodriguez, K. Garbev, D. Merz, L. Black, and I. G. Richardson, "Thermal stability of CSH phases and applicability of Richardson and Groves' and Richardson C-(A)-SH(I) models to synthetic C-S-H," Cement and Concrete Research, vol. 93, pp. 45-56, 2017.

[48] H. Dongshuai, L. Zeyu, Z. Peng, and D. Qingjun, "Molecular structure and dynamics of an aqueous sodium chloride solution in nano-pores between portlandite surfaces: a molecular dynamics study," Physical Chemistry Chemical Physics, vol. 18, no. 3, pp. 2059-2069, 2016.

[49] Y. Villagrán-Zaccardi, H. Egüez-Alava, K. De Buysser, E. Gruyaert, and N. De Belie, "Calibrated quantitative thermogravimetric analysis for the determination of portlandite and calcite content in hydrated cementitious systems," Materials and Structures, vol. 50, no. 3, p. 179, 2017.

[50] L. Nicoleau, E. Schreiner, and A. Nonat, "Ion-specific effects influencing the dissolution of tricalcium silicate," Cement and Concrete Research, vol. 59, pp. 118-138, 2014. 


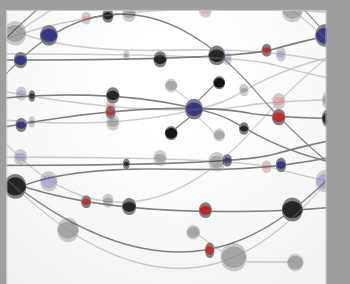

The Scientific World Journal
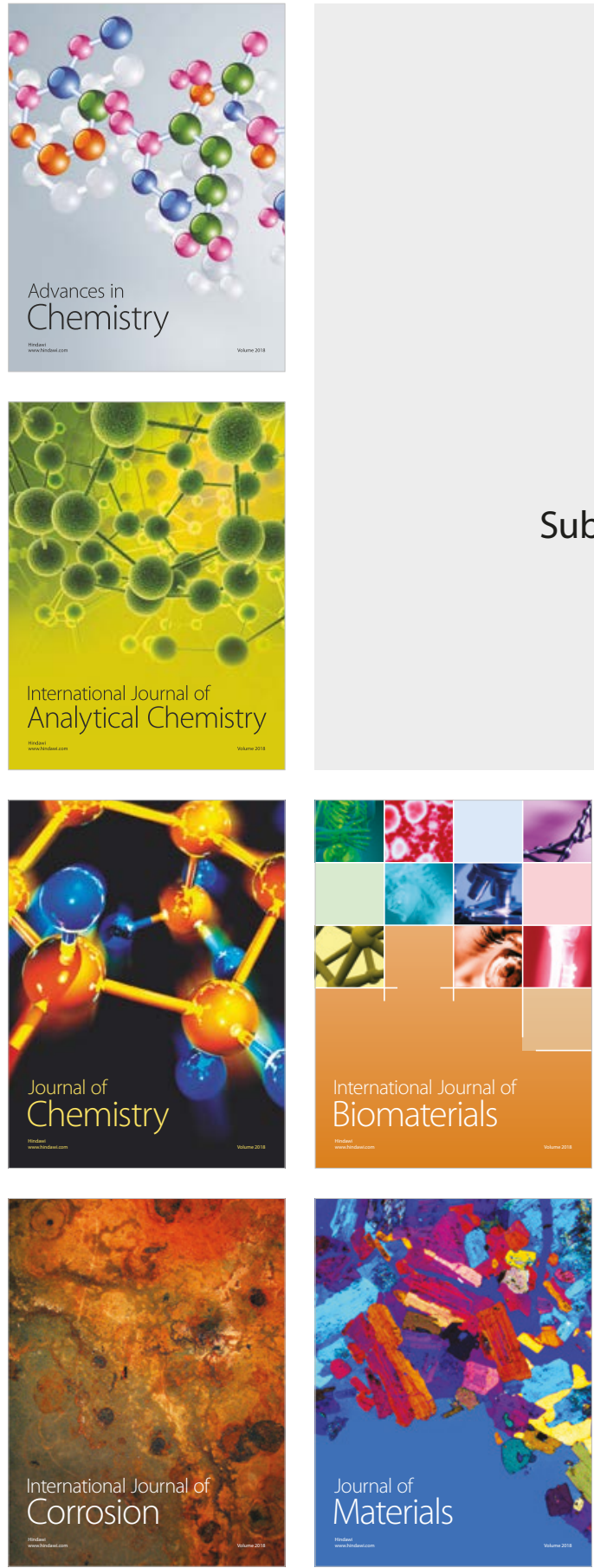

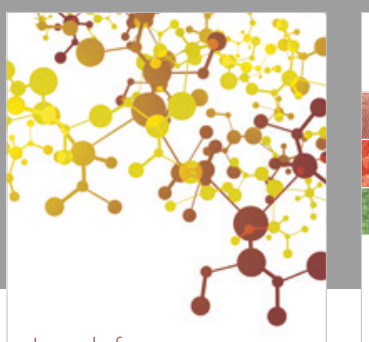

Journal of

Applied Chemistry
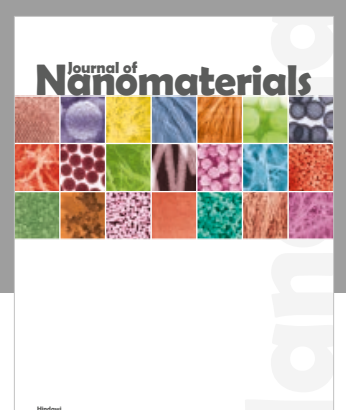

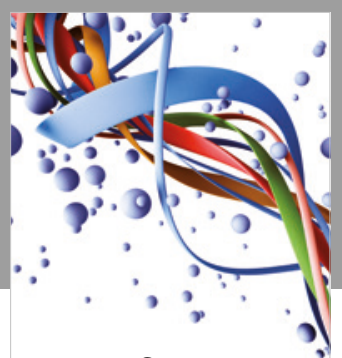

Scientifica

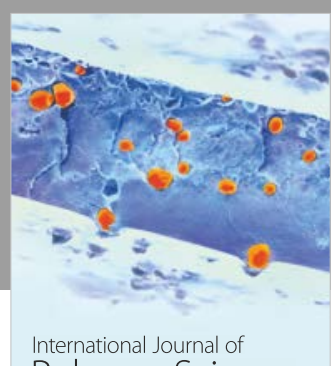

Polymer Science

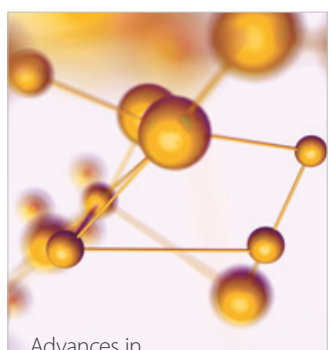

Physical Chemistry
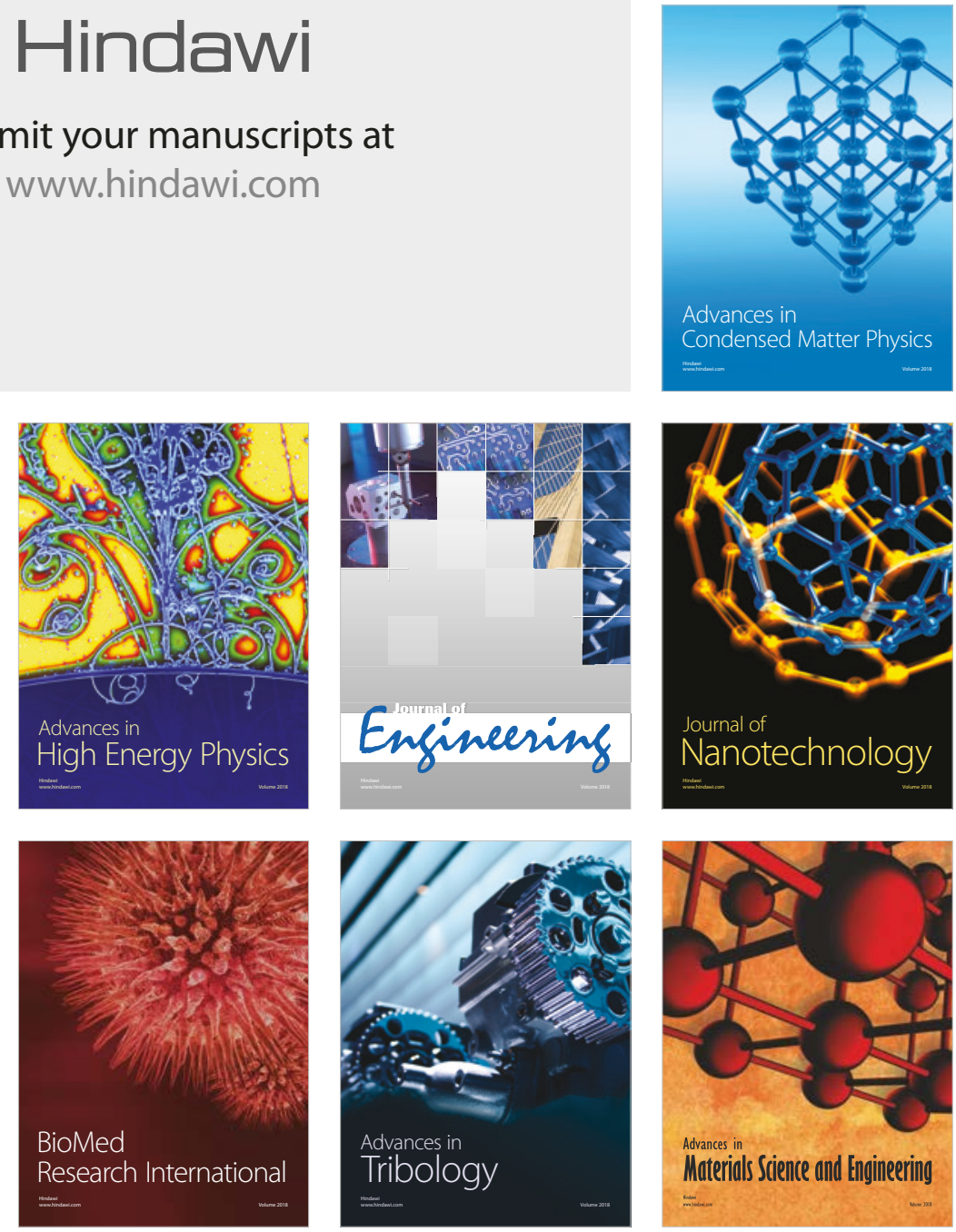